\title{
Selvmord i sagaene
}

Ved Jon Geir Høyersten

Selumord er relativt sjeldent skildret i sagaene. Suicidalhandlinger hørte imidlertid neppe med til de heroiske og handlingspregede idealer som var noe av denne litteraturens saerpreg. De eksemplene som blir referert, finnes i Snorres kongesagaer, i de islandske aettesagaene, samt i Eddadiktene. Alle disse tekstene omhandler en førkristen verden, dens verdensbilde, menneskebilde og livstolkning, der suicid var akseptert under visse omstendigheter. Kristendommens fordømmelse av suicid kommer knapt til uttrykk i sagalitteraturen.

\section{Hva er sagalitteratur?}

De islandske ættesagaene (islendingesagaene) og Snorres kongesagaer (Heimskringla) er hovedbjelkene i den norrøne prosalitteraturen. De har et legendarisk ry for sine menneskeskildringer og psykologiske innsikt. Og det er et representativt register av almenpsykologisk virkelighet som holdes frem: forskjellige adferdsmønstre, personlighetsvarianter og -forstyrrelser, konflikttyper, krisereaksjoner (Høyersten 1993), samt eksempler på alvorlig psykopatologi (Retterstøl 1962). Sagatekstene utgjør, med sin psykologiske realisme, samlet et noe nær universelt gyldig eksposé over menneskelige muligheter og avveier.

Vi har å gjøre med en litteratur som fremviser forunderlig avanserte trekk innen sin samtids høymiddelalderlige Europa, i sine skildringer av "vanlige mennesker" i hverdag, ufred og nedslaktning. Den røper impulser fra skolastisk teologi og filosofi, noe som også vitner om hvilket utrolig levende og mottagelig intellektuelt miljø som fantes på 1200-tallets Island. Menneskeskildringene er korthugne og inspirert av et ideal om vitenskapelig rasjonalitet; psykologien avspeiler ikke minst 1200-tallets psykologiske forståelse, selv om den foregir å formidle mentalitet og holdninger typiske for sagatidens mennesker (Høyersten 1998, s.157-65). Islendingesagaene, hvis forfattere er ukjente, og Heimskringla er fiksjonslitteratur som på samme tid representerer historisk kildemateriale.

Et litt sjablongmessig bilde av denne litteraturen er nok utbredt: nemlig at det stort sett dreier seg om heroiske mannlige helter, sterke, eggende kvinner, drap, grusomheter, blodhevn osv.. Men understrømmen av sorg, vemod og depresjon, ikke minst hos kvinnene, og hyppig iblandet ubendig sinne, samt varierte emosjonelle uttrykk - i kjølvannet av drap og tap er tydelig nok! Hva så med fremstillingen av selvmordet?

\section{Et dokumentert tilfelle}

Aller først en kort beretning fra et verk utenom de nevnte kategoriene, nemlig Landnåmsboken (1997), opprinnelig skrevet på 1100-tallet, en unik historiekrønike over hovedpersonene som tok land på Island ( 870-930). Den forteller om Illuge raude at ".-.han byttet både land og kone og alt feet med Holm-Starre, ---men Sigrid hengte seg i hovet, for hun ville ikke være med på byttet".

I fornaldersagaen Hervars saga berettes om Ögn, en av de kvinnelige hovedpersonene, at hun ikke vil ha mannen hun skal giftes bort til. Hun avgjør dette ved å kaste seg over et sverd. (Fornaldersagaene omhandler særlig stoff fra vikingtid og er nedskrevet fra 1250 til ut i 1400-årene).

De to episodene handler altså henholdsvis om svik i kjærlighet/forskytelse og fortvilet protest mot et ikke- $\varnothing$ nsket gifte. Det at Sigrids selvmord i det hele tatt blir omtalt, beror muligens på det "spektakulære" ved at hun hengte seg i selve gudehovet. Hva angår Ögns selvmord, skal minnes om at ekteskapet i det norr $\varnothing$ ne ættesamfunnet dessuten var et sentralt instrument for å knytte forbindelser ættene imellom: men det var ikke slik at kvinnene intet hadde de skulle sagt; den fornuftige far rådspurte nok også datteren selv, selv om initiativet ikke var kommet fra henne selv.

\section{Det store helteepos og den store sorg}

En av de mest skattede sagnkretser opp gjennom germansk og nordisk vikingtid og middelalder er heltediktningen om Sigurd Fåvnesbane. Den fikk sitt kunstneriske utrykk i Edda-diktene (1975) som også regnes som opphavet til en prosavariant, Volsungesagaen (1907), en fornaldersaga fra slutten av 1200-tallet.

Helten Sigurd blir drept av sine egne, edsvorne svogere, etter intriger fra deres søster Brynhild. Både Brynhilds og enken Gudruns sorgreaksjon skildres, og dét som ulikeartede følelseskomplekser. For Gudruns del er det først og fremst dødslengselen, med en sorg som også bar bitterhet og sinne samt emosjonslammelse i seg: "Gudrun mente /hun måtte $\mathrm{d} \phi /(\ldots)$ hun vred ikke hender, og hulket sårt,/klaget ikke/som kvinner pleier. [...] Men gråte maktet/Gudrun ikke,/av bitter sorg ville brystet sprenges,/---/ stivnet av sorgen/...) fylt av harme /(...)/" (Edda-dikt, Det første Gudrunkvadet, 1975, s. 241-246) (ill.1).

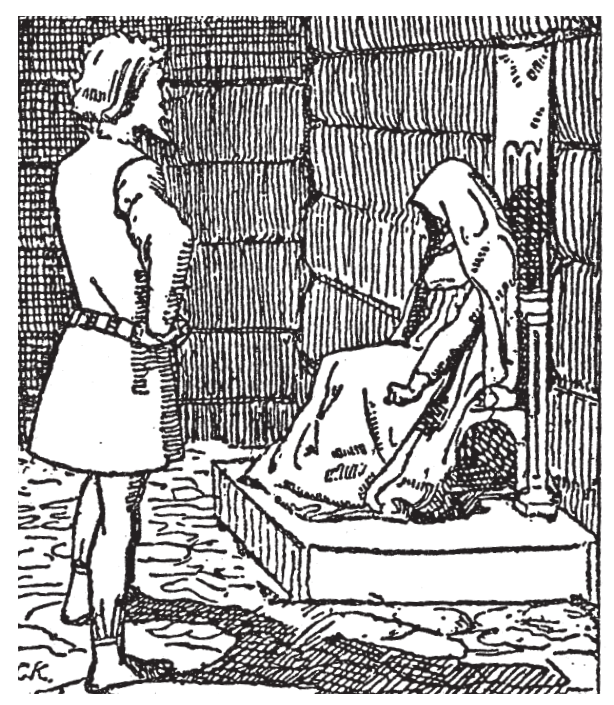

Ill. 1. I Christian Kroghs strek skildres en annen dronnings - Gunnhilds - sorg ved budskapet om ektefellens død.

(Dødslengsel i sorgen finner vi tilsvarende skildret i Egilssoga (1950), med Egil Skallagrimssons sørgekvad over tapet av sønnen Bodvar.)

Kvinnene prøver å hjelpe henne i sorgarbeidet; det må synes sannsynlig at man tok hennes d $\varnothing$ dsønske alvorlig og fryktet for hennes liv. Deres "teknikker" for lindring og hjelp gjennom sorgarbeidet (og "selvmordsprofylakse") består bl.a i aller først å holde frem fellesskapet i lidelsen, ved at de forteller om egne tap og sorger - uten at dette har noen virkning: Først da søsteren Gullrand sier "vis henne heller høvdingens ansikt/ (...)/se på den kjære/ og kyss hans munn, slik du gjorde/da Sigurd levde!”, brytes den emosjonelle sperre, og "... regn av tårer rant over kne". 


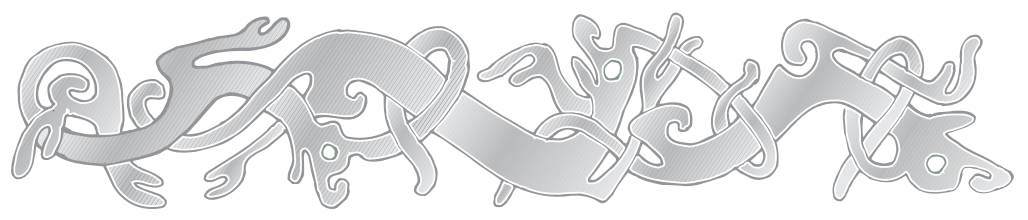

Forfatteren/kulturen hadde altså en forståelse av hva som hørte med til en gjennomarbeidet sorg: Det var viktig å vise følelser, samt få se og røre ved avd $\varnothing$ de. Slik lest må dette diktet ha hatt et preg av lærestykke, som dessuten målbar erfaringer nedfelt $\mathrm{i}$ alle kulturer til alle tider (Rosenblatt, Walsh \& Jackson 1976).

Med Brynhild, mordets initiator, hadde derimot hverken diktet eller prosaversjonen synderlig medf $\varnothing$ lelse. Selve hennes motiv for å egge til drap forstår sagaen, men hennes emosjonelle reaksjon får til dels mennene til å undres. På den ene siden rapporteres at hun hadde ledd over mordet, slik at "- bøen ga gjenlyd, .." (skildring av paradoksal sorgreaksjon (?), "begravelsesmani", et fenomen vi kjenner også i dag). Men responsen hos tilskuerne tyder på at her så man en kvinne med dobbelte og utspekulerte motiver, noe som også kom til syne i selve hennes emosjonelle respons, med mer aggressivitet og ambivalente følelser i bildet enn hos Gudrun. Komplekset av hat - kjærlighet må rimeligvis ha vært en intens drivkraft. Aggresjonen er åpen og likefrem. "Hun fnøs eiter/ $\varnothing y n e n e$ flammet ved synet av såret på Sigurds lik, ..." Dette var trolig å forstå som et suicidalvarsel; den detaljerte fremstillingen av Brynhilds motstridende følelser, kombinert med en uopprettelig skjensel og æreløshet (hun var blottstilt som løgner), - og vi må anta en aggresjon vendt innover - alle disse faktorene tilsa at det selvmord som skulle følge var like forståelig som forventet. Ytterligere bekreftet blir en slik anelse ved hennes lange enetale, før hun stikker sverdet i siden. Hun erklærer at hun egentlig bare hadde elsket én mann, “ sin første mann”, Sigurd. Og hun forteller at hun hadde befunnet seg i et avsindig dilemma - drapet så hun som eneste utvei. Både ektemannen Gunnar og alle sveinene "talde henne av med å døy, (...) men ho skuva frå seg kvar ein som kom til henne, og sagde det kunne ikkje hjelpe å telje henne ifrå det som ho hadde etla seg til". (Soga um Volsungarne 1907). Men svogeren Hogne ser ingen grunn til å “..- hindre den lange ferden, ..”. Og Gunnar, mannen, "gikk sorgfull/fra samtalen;". Man lar altså i siste instans suicidalkandidaten få sin vilje, det er grenser for konsekvent å hindre henne fysisk. Når Brynhild i sin lange monolog på dødsleiet dessuten sier «elsk har jeg savnet all min livsdag», blir det for oss fristende å postulere at en grunnleggende avvisningsproblematikk blir av psykologisk betydning for det raseri den forrådte kjærligheten avf $\varnothing$ der.

\section{Førkristent - kristent: selv- oppofrelse eller selvmord?}

I Harald Hårfagres saga beretter Snorre om kong Herlaug i Namdalen: Etter at kong Harald har tatt hans land, lar han seg begrave levende med 12 mann.

I Njåls saga er en kulminasjon av tragiske hendelser og blodhevn innebrenningen av Njål og hele hans huslyd. Før huset påtennes gis kvinner og barn og huskarer lov til å komme ut, sammen med Njål selv (Njåls soga 1975); men Njål svarer: "Eg vil ikkje gå ut, for eg er ein gamal mann, og lite skikka til å hemna sønene mine, og ikkje vil eg leva med skam”. Heller ikke hustruen, Bergtora, vil ta imot tilbudet. Endog datters $\varnothing$ nnen, Tord, sier at han aldri vil skilles fra bestemoren: "Ho bar då guten bort til senga. (...) Så signa dei seg og guten og gav si sjel i Guds hand, og det var det siste folk høyrde frå dei".

Kong Herlaug og mennenes kollektive selvmord fant sin begrunnelse i æreskodeksen; tilsvarende var en slik begrunnelse for Njål nærmest som en reminisens midt i det faktum at han var blant de første kristnede høvdinger på Island. Men hans og hustruens beslutning var arkaisk og uholdbar i forhold til kristendommens kategoriske fordømmelse av selvmordet. Og skjønt - kanskje har forfatteren skutt inn et slags evangelisk moment med det forhold at de ved å gå frivillig i døden sparte menneskene angriperne - for ytterligere blodsutgydelser (?). I så fall står vi strengt tatt ikke overfor et suicid i snever forstand, men snarere et sosialt/institusjonalisert selvmord, nærmest som et overgangsfenomen mot den oppofrende selvvalgte $\mathrm{d} \varnothing \mathrm{d}$.

\section{Psykosen som fritagelse fra synd}

Soga om Øyrbyggjene (Eyrbyggja) har flere skildringer av folk som "går frå vitet". Ofte begrunnes dette med møtet med gjengangere. Men i ett tilfelle er årsaken overfallsmenn: trellen Ufeig “.,- vart så redd at han mest gjekk frå vitet, og flaug opp i fjellet, og derifrå ut i ein foss og drap seg" (ibid.s.81). Dette tør vel regnes som et suicid - og det eneste som refereres i denne sagaen - i følge teksten i psykotisk tilstand. Det faktum at det eneste refererte suicid forklares ut fra galskap, kan muligens tolkes som kristendommens underliggende kommentar til suicidalhandlinger, nemlig at selvmordet kan forsvares kun når det er galskapen som har drevet mennesket til selvmord: Og også skildringen av selvmordet kan forsvares under denne synsvinkelen (?).

\section{Sagaens selvmord og det 20. århundres psykologi}

Måten selvmordsadferden, dens grunner og psykologiske karakteristika omtales på, på innlevende vis, tyder avgjort på at selvmord ikke kan ha vært noe totalt fremmed, bare et historisk eller «eksotisk» fenomen, for sagaforfatterne og deres norrøne samfunn i det 12 . århundre.

En fellesnevner for samtlige skildrede selvmord og selvmords $\varnothing$ nsker er forutgående tap av ens nærmeste - for kvinnenes del alltid tap av den elskede, eventuelt forsmådd kjærlighet. Og tap av ære, - i en grad som må fortone seg fremmed for dagens nordeuropeere. Alvorlige depresjoner i forbindelse med sorg og tap har sagaene tallrike eksempler på (ill.2).

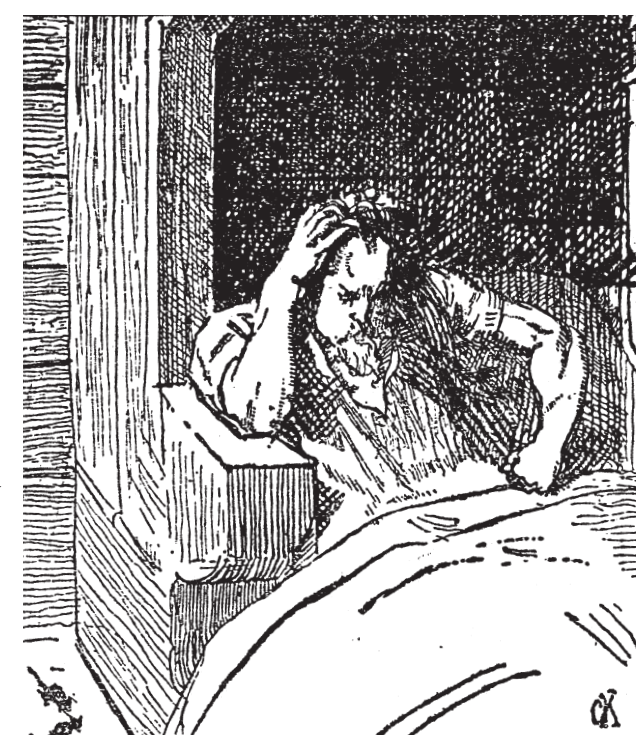

Ill.2. Christian Krogh formidler Håkon Jarls depresjon. 
Ill. 3: Helten Sigurd dreper dragen Fårne. Sigurdristningen fra tidlig 1000-tall, på Ramsundaberget $i$ Södermannland, Sverige.

At den suicidale impuls hos den dypt depressive ikke har vært til stede i vesentlig grad hos mennesket i middelalder og vikingtid er lite sannsynlig; like lite som at denne impulsen skulle kunne temmes i avgjørende grad gjennom religiøse og kulturelle tabuer.

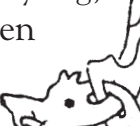
At menneskene generelt hadde bredere og tettere nettverk enn dagens mennesker i Norden, kan tenkes som en delvis beskyttende faktor.

At personen i sorg dessuten forholdt seg til sin sorg med andre mestringsmekanismer enn nu om stunder, kan også tenkes å ha vært utslagsgivende. Helt generelt tyder det meste av mentalitetsforskningen og sagaeksemplene på at Nordens mennesker for 800-1100 år siden hadde mindre hemninger i forhold til utlevelse av instinkter, samt at de i større grad brukte psykologiske eksternaliseringsmekanismer. Eksempel på det siste er at menn drar ut i viking, herjer og dreper, slik det fortelles om danekongen Ragnar Lodbrok (fra midten av 800 tallet), etter at dronningen hans d $\varnothing$ de.

Kvinnenes egging - oftest til hevndrap - kan tilsvarende tenkes å ha gitt en emosjonell tilfredsstillelse og utladning ved at aggresjonen blir kanalisert ut mot en opprinnelig drapsmann eller en som har trådt ens ære for nær. I noen grad har den eggende kvinnen da unngått det altfor smertefulle ved bare å holde sitt sinne innelukket $-i$ verste fall rettet det innad mot seg selv.

\section{Diskusjon og kommentar}

De refererte eksemplene på suicid omfatter hva jeg har kunnet oppspore innen den norrøne litteraturen, hvis temaer hovedsakelig er mennesker og handlinger som fant sted i Norden i førkristen tid, altså 3-400 år før forfatterne levet og skrev ned. Det gjelder også skildringen av selvmordsadferd, og reaksjoner på dette, der det er den førkristne mentalitet og kontekst innen nordisk og nordgermansk område som kommer til uttrykk. I hvor sterk grad et kristent ideal generelt kommer til syne hos sagaforfatterne, hva angår menneskesyn og moral, direkte eller indirekte, er et mye diskutert spørsmål.

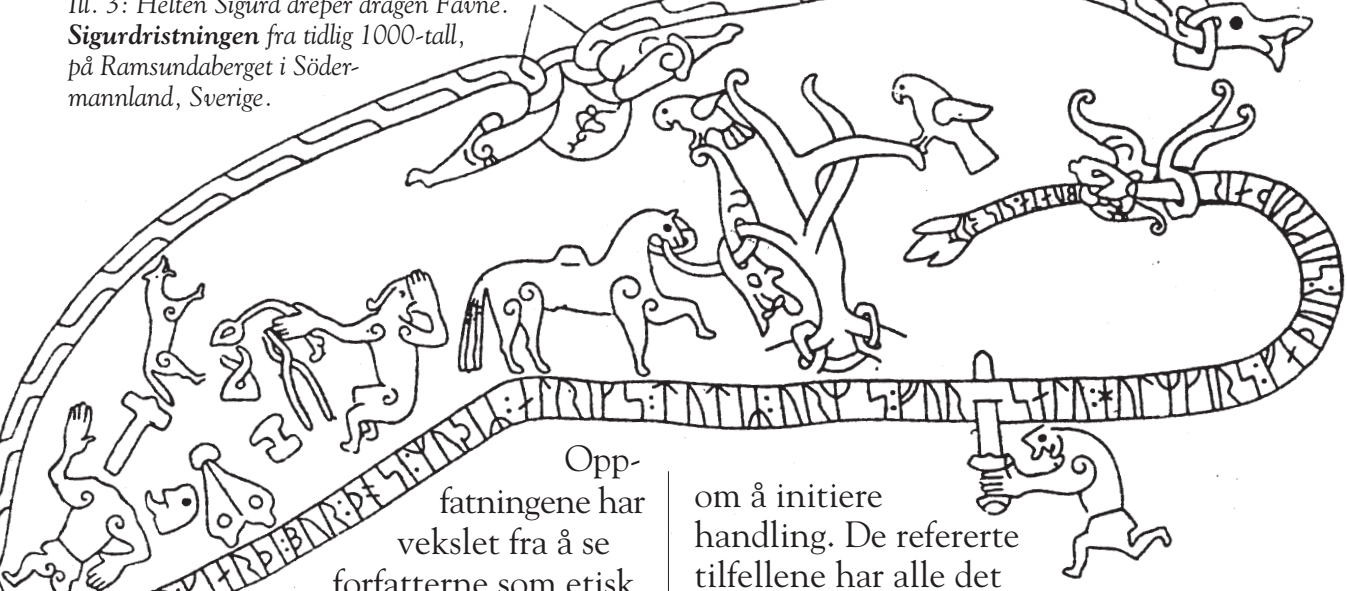

forfatterne som etisk

indifferente til at de egentlig målbærer sin egen samtids etikk, preget av høyskolastikken på 1100-tallet (Pálsson 1974; Høyersten 1998, s.222249). Det er sagaenes litterære styrke at de søker å gjenskape et innforlivet bilde av forfedrenes handlingssett, tankegang og verdinormer, uten å moralisere ved å påpeke, formane eller ford $\varnothing \mathrm{mme}$. Ut fra en slik forståelse av sagatekstene må det f.eks. forefalle usannsynlig at deres opphavsmenn skulle ha behov for spesielt å ekskludere temaet selvmord. Alt i alt illustrererer de refererte eksemplene hva som anses som en forn-germansk arv i Norden, nemlig at suicid ble sett som tjenlig og akseptert for å unngå fattigdom, alderdom og vanære, - eventuelt for å følge noen i døden (Strøm 1970). A begå suicid kaltes å vie seg til Odin ("vígja sik Ódni”). En sterk tradisjonell overlevering vitner om dette: Betegnelsen Ættarstup (Atternisstapi) refererte til en bratt bergvegg , anvendt av en hel slekt for frivillig eller ved tvang å forkorte livet på gamle og syke eller på seg selv (Strøm 1976). Tildragelsen i Njåls saga kan, liksom mye av handlingen ellers, ses som hedenske reminisenser. Men sagaene kan knapt sies å målbære den kategoriske fordømmelse av selvmordet, som kom med kristendommen.

Sammenholdt med de hundrevis av drap som refereres i islendingesagaene og hos Snorre - særlig under blodhevnens merke - vil vi kanskje synes at det til sammenligning må foreligge et åpenbart misforhold hva antall refererte suicidhandlinger angår, om da sagaene skulle forventes å gi en psykososial, "epidemiologisk" virkelighetsbeskrivelse, deres karakteristiske hverdagsrealisme til tross. Vi må huske på at sentralt for sagaenes litterære egenart og dynamiske kraft er vektleggingen av handling og handlende mennesker, det vil si stort sett av heroisk art. Også kvinnenes særlige kommunikative evner, med å egge mennene til dåd, dreier seg tilfellene har alle det

særpreg at rammen, gjennomf $\varnothing$ ringen og foranledningen til suicidet var klart spektakulær og dramatisk. (Det at Gudruns mer stillfarende sorg skildres i detalj i Eddaversjonen, mens Volsungesagaen intet har om akkurat dette, avspeiler prosasagaens mer heroiserende stil). Det må være grunn til å anta at selvmordshandlinger i forhold til dette handlingsidealet, av sagaen snarere har vært vurdert som et fenomen på linje med sykdom, lidelse og d $\varnothing \mathrm{d}$. De refererte eksemplene dreier seg om noe annet og mer enn personer som bare forsvinner stille ut av livet. At det derved også var storslagent litterært stoff, kan vel ha vært medvirkende til at det ble funnet verdig litterær behandling. Suicidalhandlingene fikk som funksjon å illustrere dramaets intense og tragiske alvor ved å synliggjøre såvel selvmordets beveggrunner som dets gjennomføring og omgivelsenes fortvilte reaksjoner.

\section{Litteratur}

Edda-dikt. Overs. av Holm-Olsen L. Oslo: Cappelen, 1975.

Egilssoga. Omsett av Leiv Heggstad. Oslo: Samlaget, 1950.

Høyersten J G. Sorg og kriser i norrøn litteratur. Tidsskrift for Den norske lægeforening 1993; 113 (9): 1086-1091.

Høyersten J G. Personlighet og avvik. En studie i islendingesagaenes menneskebilde, med særlig vekt på Njála.(dr. avh.). Bergen 1998.

Landnåmsboken. Innledning og noter av Hermann Pálsson. Oslo: Aschehoug, 1997.

Forts. side 8

Jon Geir Høyersten er dr. philos. (på en avhandling om menneskebildet $\mathrm{i}$ islendingesagaene), er

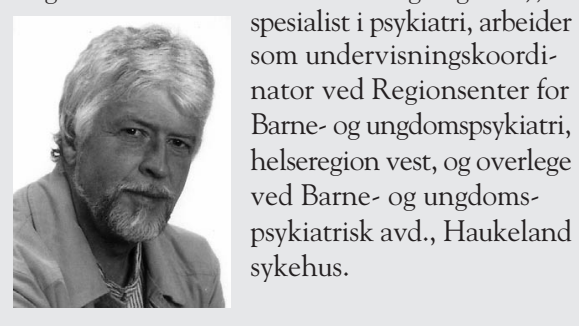

Prof. dr. philos. Else Mundal,

Nordisk inst., Universitetet $i$ Bergen, takkes

for gjennomlesning av manuskriptet og for gode råd. 


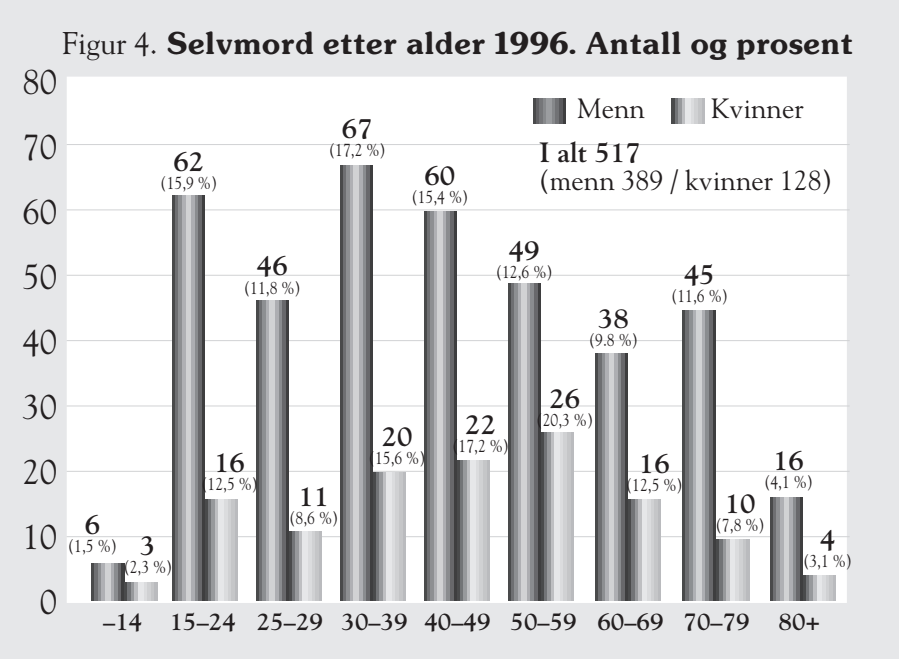

Kilde: NOS Dødsårsaker 1996. Statistisk sentralbyrå

to tilfeller årlig i 1970-74). I 1996 ble det registrert 68 selvmord blant unge menn under 25 år, en nedgang fra $96 \mathrm{i}$ 1988, 94 i 1991 og 1992 og 75 i 1995.

\section{Faerre dødsulykker}

Nedgangen i selvmordstallene har skjedd samtidig med at antall ulykker med dødelig utgang har blitt redusert. I femårsperioden 1986-90 var det et årlig gjennomsnitt på 1990 dødsulykker.
Tilsvarende tall var redusert til $1769 \mathrm{i}$ 1991-93, med en ytterligere nedgang til I 673 dødsulykker i 1996. I 1996 ble det kun registrert $16 \mathrm{~d} \varnothing \mathrm{dsfall}$ med uklar ytre årsak til forgiftning og skade, mens tilsvarende tall i 1995 var 18 .

Finn Gjertsen er sosiolog og rådgiver i Statistisk sen tralbyrå, Seksjon for helsestatistikk og har i flere år hatt faglig ansvar for nasjonal dødsårsaksstatistikk. Han har videre publisert arbeider om selvmord og ulykker, alene og i samarbeid med andre.
Forts. fra s. 6

\section{Anbefalinger i det videre selvmordsforebyggende arbeid}

Helsetilsynet har ved siden av allerede beskrevne tiltak foreslått følgende hovedsatsingsområder i det videre selvmordsforebyggende arbeid:

- Tilbudet til barn og unge

- Eldre

- Arbeidsplassen

- Personellgrupper som yrkesmessig kommer i kontakt med mennesker i selvmordskriser
- Homofile og lesbiskes situasjon

- Oppfølgingstilbudet til pårørende etter selvmord

Det gjenstår å avklare flere premisser i forbindelse med det nye prosjektet som nå skal etableres. Helsetilsynet vil i arbeidet med å konkretisere tiltak samarbeide med Handlingsplanens referansegruppe, det nasjonale kompetansesenter og de regionale ressursmiljøer.

Videreføringen organiseres som et treårig prosjekt forankret i Helsetilsynet,

\section{Litteratur}

Dagens statistikk. D $\phi$ dsårsaker 1996.

Færre selvmord. 30. sept. 1999.

Statistisk sentralbyrå http:www.ssb.no

Dødsårsaker 1995. NOS C 490.

Oslo-Kongsvinger: Statistisk sentralbyrå 1998

Dфdsårsaker 1996. NOS. Under produksjon, november 1999

Gjertsen F. Utviklingstendenser i selvmord 1950-1995. Nytt i suicidologi 1998; 3 (2): 8-11



\section{Forts. fras. 5}

Njåls soga. Omsett av Aslak Liestøl: Oslo: Samlaget, 1975.

Pálsson H. Icelandic Sagas and medieval ethics. Mediaeval Scandinavia 1974; 7: 61-65.

Retterst $\varnothing 1$ N. Psykiatriske synspunkter på persongalleriet i Snorres kongesagaer. Tidsskrift for Den norske lægeforening 1962; 18: 1219-1222.

Rosenblatt PC, Walsh RP, Jackson D. Grief and mourning in crosscultural perspective. New Haven, Conn.: HRAF Press, 1976.
Soga um Volsungarne. Omsett av Torleiv Hannaas. Oslo: Samlaget, 1907.

Soga om Øyrbyggiene. Omsett av Jostein Høgetveit. Oslo: Samlaget, 1939.

Strøm A V. "Självmord”, I: Kulturhistorisk leksikon for nordisk middelalder. Oslo: Gyldendal, 1970. Bd. XV. s. 331-334.

Strøm A V. “Ättestupa” I: Kulturhistorisk leksikon for nordisk middelalder. Oslo: Gyldendal, 1976. Bd. XX. s. 601-603.
Avdeling for spesialisthelsetjeneste. Det vil fortsatt bli en sentral prosjektledelse og styringsgruppe. Nåværende referansegruppe opphører fra 1. januar 2000, og erstattes av en ny.

Nils Petter Reinholdt er
nasjonal prosjektleder for
Handlingsplan mot selvmord
og ansatt i Helsetilsynet.
Han er psykiatrisk sykepleier
og ledet et lokalt handlings-
planprosjekt i Oppdal fylke.

Suicidologi nr. 1 - 2000

utkommer i mars.

Frist for innlevering av bidrag er 15. januar. 